\title{
Chryseobacterium haifense sp. nov., a psychrotolerant bacterium isolated from raw milk
}

Correspondence

Malka Halpern

mhalpern@research.haifa.ac.il

\author{
Elionora Hantsis-Zacharov ${ }^{1}$ and Malka Halpern ${ }^{1,2}$
}

${ }^{1}$ Department of Evolutionary and Environmental Biology, Faculty of Science and Science Education,
University of Haifa, Mount Carmel, Haifa 31905, Israel
${ }^{2}$ Department of Biology, Faculty of Science and Science Education, University of Haifa, Oranim,
Tivon 36006, Israel

Strain $\mathrm{H}_{3} 8^{\top}$ was isolated during a study on the diversity of culturable psychrotolerant bacteria in raw milk. Comparative 16S rRNA gene sequence analysis showed that strain $\mathrm{H}^{3} 8^{\top}$ belongs to the genus Chryseobacterium (family Flavobacteriaceae, phylum Bacteroidetes), with the highest similarity (96.7\%) to Chryseobacterium hispanicum VP48 ${ }^{\top}$. Strain $\mathrm{H}^{3} 8^{\top}$ grows aerobically, at $4-41{ }^{\circ} \mathrm{C}$, with $0-2.5 \% \mathrm{NaCl}$ and at $\mathrm{pH}$ 6.5-10.5. Light induces the formation of yellow carotenoid pigments. The dominant cellular fatty acids are $15: 0$ iso (41.6\%), $15: 0$ anteiso $(16.6 \%)$ and $17: 0$ iso $3-\mathrm{OH}(10.3 \%)$. The $\mathrm{G}+\mathrm{C}$ content of the DNA is $37.8 \mathrm{~mol} \%$. On the basis of its phenotypic properties and phylogenetic distinctiveness, strain $\mathrm{H}^{3} 8^{\top}$ (=LMG $24029^{\top}$ $=\mathrm{DSM} 19056^{\top}$ ) is classified in the genus Chryseobacterium as the type strain of a novel species, for which the name Chryseobacterium haifense sp. nov. is proposed.
The genus Chryseobacterium is a member of the family Flavobacteriaceae, phylum Bacteroidetes, and currently consists of 19 species, with Chryseobacterium gleum as the type species (Vandamme et al., 1994). Two additional species were recently transferred to the new genus Elizabethkingia (Kim et al., 2005b). Most members of the genus Chryseobacterium are widely distributed in aquatic and soil environments. Other Chryseobacterium species are pathogenic to humans and animals (Bernardet et al., 2002, 2005, 2006). Chryseobacterium strains are also part of the psychrotolerant and proteolytic bacterial population that causes a variety of defects in food products such as processed meats, chilled fish and shellfish and dairy products (González et al., 2000; Hugo et al., 1999, 2003).

Strain $\mathrm{H} 38^{\mathrm{T}}$ was isolated in the course of a study on the diversity of culturable psychrotolerant bacteria in raw milk. Raw milk from four farms in Israel was sampled every other month from April 2004 to January 2005. The samples were serially diluted and plated on sterile standard plate count (SPC) agar (Oxoid CM0463). Plates were incubated at $7{ }^{\circ} \mathrm{C}$ for 10 days and colonies that displayed distinct morphologies were subcultured to obtain pure cultures. Among about 300 pure cultures isolated in this study, strain $\mathrm{H} 38^{\mathrm{T}}$ was isolated on SPC agar during the sampling of April 2004. A comparative analysis of $16 \mathrm{~S}$ rRNA gene sequences indicated that strain $\mathrm{H} 38^{\mathrm{T}}$ was a member of the genus Chryseobacterium. In order to determine its exact taxonomic position, a polyphasic taxonomic study was carried out.

The GenBank/EMBL/DDBJ accession number for the 16S rRNA gene sequence of strain $\mathrm{H}_{3}{ }^{\top}$ is EF204450.
The universal bacterial primers $8 \mathrm{f}$ and 1512r (based on Escherichia coli positions) were used to amplify internal fragments of the 16S rRNA gene according to Felske et al. (1997). The amplified PCR product (approx. $1.5 \mathrm{~kb}$ ) was purified using a Wizard PCR product purification kit (Promega). Purified PCR products were sequenced at Technion Medical School (Haifa, Israel) directly by the dideoxynucleotide chain-termination method using a DNA sequencer (ABI PRISM 3100) with BigDye terminator reagents (Applied Biosystems) according to the manufacturer's instructions. Sequencing was performed by using primers 8f (5'-GGATCCAGACTTTGATYMTGGCTCAG$\left.3^{\prime}\right)$, 534r (5'-ATTACCGCGGCTGCTGG-3'), 968f (5' AACGCGAAGAACCTTAC-3') and 1512f (5'-GTGAAGCTTACGGYTAGCTTGTTACGACTT-3'). The newly determined sequence (1480 bp) was compared to those available in EMBL (http://www.ebi.ac.uk) using the Washington University BLAST program (version 2.0). Sequence alignment was performed using the CLUSTAL $\mathrm{W}$ program and a phylogenetic tree (Fig. 1) was generated using the neighbourjoining method in the MEGA3 software (Kumar et al., 2004).

Strain $\mathrm{H} 38^{\mathrm{T}}$ was closely related to representatives of the genus Chryseobacterium. The highest sequence similarity was $96.7 \%$, with Chryseobacterium hispanicum $\mathrm{VP} 48^{\mathrm{T}}$, and similarity values were less than $96 \%$ with the type strains of other Chryseobacterium species. The similarity between strain $\mathrm{H} 38^{\mathrm{T}}$ and members of the genera Riemerella and Elizabethkingia was less than $93.8 \%$ (Fig. 1).

For electron microscopy, bacteria were suspended in saline, fixed to a carbon-coated grid, stained with $2 \%$ uranyl 


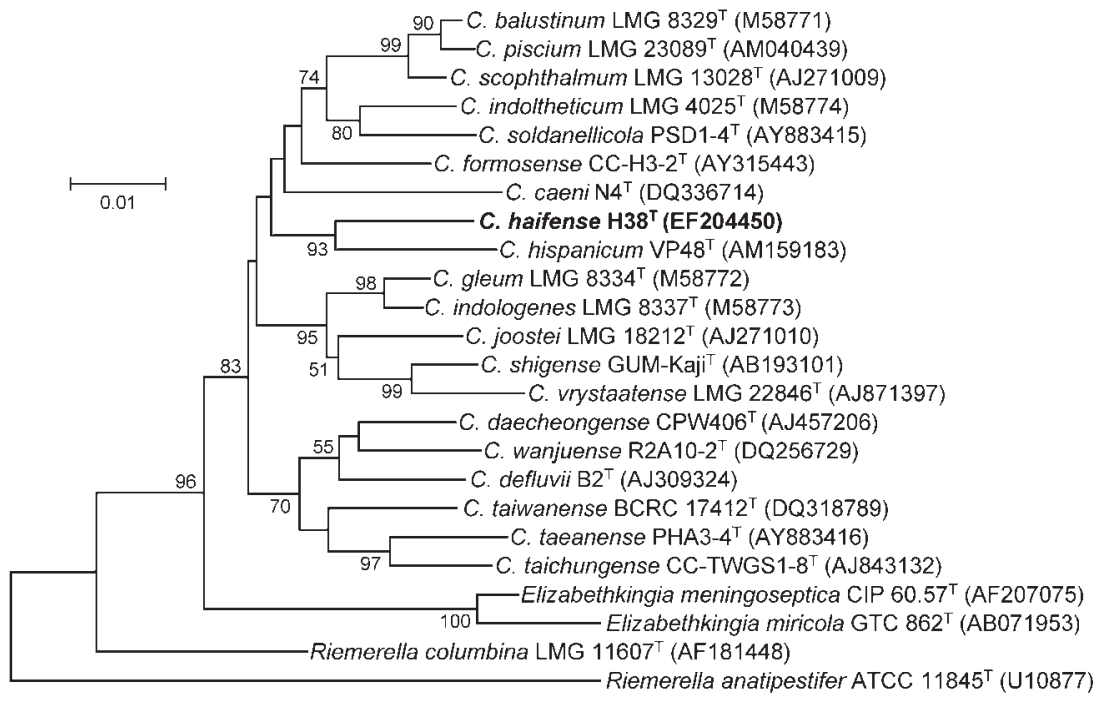

Fig. 1. Neighbour-joining tree based on $16 \mathrm{~S}$ rRNA gene sequences showing the phylogenetic positions of strain $\mathrm{H}_{3}{ }^{\top}$, other species of the genus Chryseobacterium and related taxa. Bootstrap values (>50\%) resulting from 1000 replicates are indicated at branching nodes. Bar, 0.01 substitutions per nucleotide position. acetate and photographed using a JEM-1200EX electron microscope (JEOL). Electron microscopy showed that the cells were non-flagellated rods, $0.6-0.9 \mu \mathrm{m}$ wide and 1.3$2.5 \mu \mathrm{m}$ long.

For phenotypic characterization, SPC agar was used as the basal growth medium. Salt tolerance was determined on SPC agar containing varying concentrations of $\mathrm{NaCl}$ $\left(0-5 \% \mathrm{w} / \mathrm{v}\right.$ at $0.5 \%$ intervals) at $30{ }^{\circ} \mathrm{C}$. Growth at 4,7 , $18,22,25,30,32,37,40,42,43$ and $45{ }^{\circ} \mathrm{C}$ was measured on SPC agar. The $\mathrm{pH}$ range for growth was determined using SPC adjusted to various $\mathrm{pH}$ values $(\mathrm{pH} 3.5-10.5$ at 0.5 unit intervals). The $\mathrm{pH}$ was adjusted prior to sterilization by the addition of $\mathrm{HCl}$ or $\mathrm{NaOH}$ and measured again after sterilization. Growth under anaerobic conditions was determined after incubation in an anaerobic chamber on SPC agar supplemented with $0.5 \%(\mathrm{w} / \mathrm{v})$ glucose or $0.1 \%$ $(\mathrm{w} / \mathrm{v})$ potassium nitrate. Biochemical tests were performed by using API 20E, API 20NE, API 50CH and API ZYM identification systems (bioMérieux) according to the manufacturer's instructions, except that the incubation temperature was $32{ }^{\circ} \mathrm{C}$. Catalase activity was examined by bubble production in a $3 \%(\mathrm{v} / \mathrm{v})$ hydrogen peroxide solution. Oxidase activity was determined using $1 \%$ $N, N, N^{\prime}, N^{\prime}$-tetramethyl-p-phenylenediamine dihydrochloride (Sigma-Aldrich; T3134). Growth was tested on MacConkey agar (Difco) and cetrimide agar (Himedia). Haemolytic activity was determined using blood agar base supplemented with $5 \%$ sheep blood (Hylabs). Hydrolysis of casein and tributyrin was determined using $1 \%$ skimmed milk agar supplemented with $0.5 \%$ yeast extract and tributyrin agar (Hylabs), respectively. The phenotypic traits of strain $\mathrm{H} 38^{\mathrm{T}}$ are given in the species description and in Table 1.

As all Chryseobacterium species tested so far produce flexirubin pigments, cell mass of strain $\mathrm{H} 38^{\mathrm{T}}$ was subjected to the $\mathrm{KOH}$ test as described by Fautz \& Reichenbach (1980) and Bernardet et al. (2002). A very weak colour change was observed, demonstrating that minor amounts of flexirubin-type pigments are produced. The yellow pigments were extracted and investigated according to Peterson et al. (1954). Briefly, the isolate was grown on LB agar at room temperature under light and dark conditions for $48 \mathrm{~h}$. Cells were transferred to acetone, vortexed for $1 \mathrm{~min}$, allowed to stand for $10 \mathrm{~min}$ and then centrifuged for $3 \mathrm{~min}$ at 13000 r.p.m. Spectral analysis from 250 to $700 \mathrm{~nm}$ was performed on the acetone extract. A broad peak with two shoulder peaks at 455 and $482 \mathrm{~nm}$ typical of carotenoids was observed. Hence, the yellow colour of strain $\mathrm{H} 38^{\mathrm{T}}$ mostly results from the production of carotenoid pigments under light conditions.

For cellular fatty acid analysis, cells were cultured on tryptic soy agar (Difco) for $24 \mathrm{~h}$ at $28{ }^{\circ} \mathrm{C}$ and then the fatty acids were extracted and methylated (Ben-Ze'ev et al., 2005). The fatty acid methyl esters were analysed by gas chromatography using the MIDI/Hewlett Packard microbial identification system (Analytical Services Inc.). The major fatty acids $(>10 \%)$ of strain $\mathrm{H} 38^{\mathrm{T}}$ were $15: 0$ iso $(41.6 \%), 15: 0$ anteiso $(16.6 \%)$ and $17: 0$ iso $3-\mathrm{OH}(10.3 \%)$.

For determination of the DNA $\mathrm{G}+\mathrm{C}$ content, genomic DNA of strain $\mathrm{H} 38^{\mathrm{T}}$ was prepared according to a modification of the procedure of Wilson (1987). The DNA G+C content was determined using HPLC analysis of hydrolysed DNA according to Mesbah et al. (1989). The analysis was performed by the BCCM/LMG Bacteria Collection Identification Service (Laboratory of Microbiology, Ghent University, Belgium). The $\mathrm{G}+\mathrm{C}$ content of strain $\mathrm{H} 38^{\mathrm{T}}$ was $37.8 \mathrm{~mol} \%$.

Strain $\mathrm{H} 38^{\mathrm{T}}$ was isolated in the course of a study of the psychrotolerant bacterial community in raw milk and of its proteolytic and lipolytic activities (unpublished results). Five per cent of the isolates were members of the genus Chryseobacterium that possessed a variety of proteolytic and lipolytic activities. Of them, four strains shared 97.5-100.0\% 16S rRNA gene sequence similarity with 
Table 1. Differentiating characteristics of strain $\mathrm{H}_{3} 8^{\top}$ and other Chryseobacterium species

Taxa: 1, strain $\mathrm{H}_{3} 8^{\mathrm{T}}$ (C. haifense sp. nov.); 2, C. gleum ( $\left.n=12\right) ; 3$, C. balustinum; 4, C. indologenes ( $\left.n=13\right) ; 5$, C. indoltheticum; 6, C. scophthalmum $(n=7) ; 7$, C. defluvii; 8, C. joostei $(n=11) ; 9$, C. daecheongense; 10, C. formosense; 11, C. taichungense; 12, C. shigense; 13, C. vrystaatense ( $n=36) ; 14$, C. soldanellicola; 15, C. taeanense; 16, C. piscium ( $n=4) ; 17$, C. hispanicum; 18, C. wanjuense; 19, C. taiwanense; 20, C. caeni. Data from Yabuuchi et al. (1983), Holmes et al. (1984), Hugo et al. (2003), Kämpfer et al. (2003), de Beer et al. (2005, 2006), Kim et al. (2005a), Shen et al. (2005), Shimomura et al. (2005), Young et al. (2005), Gallego et al. (2006), Park et al. (2006), Tai et al. (2006), Weon et al. (2006), Quan et al. (2007) and this study. The number of strains examined is shown in parentheses when greater than one (data for other species are for the type strain only). + , Positive; w, weakly positive; -, negative; v, variable; NA, no data available.

\begin{tabular}{|c|c|c|c|c|c|c|c|c|c|c|c|c|c|c|c|c|c|c|c|c|}
\hline Characteristic & 1 & 2 & 3 & 4 & 5 & 6 & 7 & 8 & 9 & 10 & 11 & 12 & 13 & 14 & 15 & 16 & 17 & 18 & 19 & 20 \\
\hline Pigment type $(s)^{*}$ & $\mathrm{~F}(\mathrm{w}), \mathrm{C} \dagger$ & $\mathrm{F}$ & $\mathrm{F}$ & $\mathrm{F}$ & $\mathrm{F}$ & $\mathrm{F}$ & NA & $\mathrm{F}$ & $\mathrm{F}$ & $\mathrm{F}$ & $\mathrm{F}$ & $\mathrm{F}$ & $\mathrm{F}$ & NA & NA & F & $\mathrm{F}(\mathrm{w})$ & F & $\mathrm{F}$ & F \\
\hline \multicolumn{21}{|l|}{ Growth on/at: } \\
\hline $3 \% \mathrm{NaCl}$ & - & NA & $\mathrm{W}$ & + & w & $\mathrm{W}$ & - & NA & NA & NA & NA & NA & - & + & + & + & - & - & + & + \\
\hline Cetrimide agar & - & - & - & + & - & - & - & + & NA & NA & NA & NA & + & NA & NA & - & $\mathrm{NA}$ & NA & NA & NA \\
\hline MacConkey agar & - & + & + & + & + & - & - & + & - & - & - & - & - & - & - & - & - & $\mathrm{W}$ & NA & - \\
\hline $5{ }^{\circ} \mathrm{C}$ & + & - & - & - & + & + & - & + & - & - & - & + & + & + & + & + & + & + & + & + \\
\hline $37{ }^{\circ} \mathrm{C}$ & + & + & + & + & - & - & + & - & + & + & + & - & - & + & + & - & - & + & + & + \\
\hline $42{ }^{\circ} \mathrm{C}$ & - & - & - & + & - & - & + & - & - & - & - & - & - & - & - & - & - & - & + & - \\
\hline Nitrate reduction & - & NA & + & $\mathrm{V}$ & - & - & - & - & + & - & - & - & - & - & - & + & + & - & - & - \\
\hline Urease activity & - & $\mathrm{v}$ & - & - & - & + & - & $\mathrm{v}$ & - & - & - & - & + & - & - & + & - & - & - & + \\
\hline$\beta$-Galactosidase activity & + & $\mathrm{v}$ & - & - & - & + & NA & - & - & - & $\mathrm{w}$ & NA & NA & - & - & NA & + & + & - & + \\
\hline \multicolumn{21}{|l|}{ Production of: } \\
\hline $\mathrm{H}_{2} \mathrm{~S}$ & - & - & - & - & + & - & - & - & - & - & - & - & $\mathrm{v}$ & - & - & - & - & NA & - & - \\
\hline Indole & + & + & + & + & + & - & + & + & - & + & $\mathrm{w}$ & + & + & - & - & + & $\mathrm{w}$ & NA & + & - \\
\hline \multicolumn{21}{|l|}{ Acid production from: } \\
\hline Glucose & + & + & + & + & NA & - & + & + & - & w & $\mathrm{w}$ & + & NA & NA & NA & NA & + & + & - & - \\
\hline L-Arabinose & - & + & $\mathrm{NA}$ & $\mathrm{V}$ & - & - & - & - & - & - & - & - & NA & - & - & $\mathrm{NA}$ & $\mathrm{NA}$ & - & + & - \\
\hline D-Fructose & + & + & + & + & - & - & NA & + & + & $\mathrm{NA}$ & NA & + & NA & - & - & $\mathrm{NA}$ & + & - & $\mathrm{v}$ & - \\
\hline Lactose & + & - & - & - & - & - & NA & - & - & $\mathrm{NA}$ & - & - & NA & - & - & $\mathrm{NA}$ & - & - & - & - \\
\hline Maltose & + & + & - & + & + & - & + & + & - & - & + & - & NA & - & - & NA & + & - & - & - \\
\hline D-Mannitol & - & - & - & $\mathrm{V}$ & NA & - & - & $\mathrm{v}$ & - & - & - & - & NA & - & - & $\mathrm{NA}$ & - & - & - & - \\
\hline Trehalose & - & + & - & + & - & - & + & + & + & + & + & - & NA & - & - & $\mathrm{NA}$ & - & + & - & - \\
\hline D-Xylose & - & v & - & - & - & - & - & - & + & w & + & - & NA & - & - & $\mathrm{NA}$ & + & - & NA & - \\
\hline $\begin{array}{l}\text { DNA G + C content } \\
(\mathrm{mol} \%) \ddagger\end{array}$ & 37.8 & 37.6 & 33.1 & 38.5 & 33.8 & 34.2 & 38.8 & 36.7 & 36.6 & NA & $\mathrm{NA}$ & 36.6 & 37.1 & 28.8 & 32.1 & 33.6 & 34.3 & 37.8 & 36.8 & 38.2 \\
\hline
\end{tabular}

*The type of yellow pigment (when determined) is indicated by $\mathrm{F}$ (flexirubin) or C (carotenoid).

$\dagger$ Yellow pigments are produced only when bacteria are grown under light conditions.

$\ddagger$ Data for type strains (where available).

Chryseobacterium joostei, three shared $98.4 \%$ sequence similarity with Chryseobacterium scophthalmum and seven shared less than $97.5 \%$ sequence similarity with all described Chryseobacterium species (data not shown). Strain $\mathrm{H} 38^{\mathrm{T}}$ hydrolysed casein and tributyrin and showed esterase lipase and lipase activities in the API ZYM system. The activities of heat-stable proteolytic and lipolytic enzymes originating from psychrotolerant bacteria are the limiting factor in maintaining the flavour quality of fluid milk and its products. However, the impact of strain $\mathrm{H} 38^{\mathrm{T}}$ and other Chryseobacterium isolates on milk quality has yet to be determined.

Being an aerobic, non-motile rod, catalase- and oxidasepositive, with $15: 0$ iso and $17: 0$ iso $3-\mathrm{OH}$ as the dominant fatty acids, the new isolate shared the main characteristics of Chryseobacterium strains. However, strain $\mathrm{H} 38^{\mathrm{T}}$ differed from all described Chryseobacterium species by several phenotypic traits (Table 1), particularly the presence of carotenoid pigments when grown under light conditions and the large amount of the fatty acid 15:0 anteiso (16.6\%) (Bernardet et al., 2006). Strain $\mathrm{H} 38^{\mathrm{T}}$ could be distinguished from strains of $C$. joostei, also isolated from raw milk, by its ability to grow at $37{ }^{\circ} \mathrm{C}$, its inability to grow on cetrimide and MacConkey agars and its opposite results for $\beta$-galactosidase activity and acidification of lactose and trehalose.

On the basis of phenotypic characterization and phylogenetic analysis, we propose that strain $\mathrm{H} 38^{\mathrm{T}}$ be classified as the type strain of a novel species, for which the name Chryseobacterium haifense sp. nov. is proposed. 


\section{Description of Chryseobacterium haifense sp. nov.}

Chryseobacterium haifense [hai.fen'se. N.L. neut. adj. haifense pertaining to Haifa, the name of the university (University of Haifa) where this study was conducted].

Cells are aerobic, Gram-negative, non-motile rods, 0.6$0.9 \mu \mathrm{m}$ wide and $1.3-2.5 \mu \mathrm{m}$ long, occurring singly, in pairs or in short chains. Growth is not observed under anaerobic conditions. After $48 \mathrm{~h}$ incubation on SPC agar at $30{ }^{\circ} \mathrm{C}$, colonies are circular with entire edges, opaque, smooth and cream-coloured. When light is provided during growth, colonies are yellow-coloured due to the production of carotenoid pigments. Flexirubin reaction is weakly positive. Grows at $4-41{ }^{\circ} \mathrm{C}$ (optimum $32{ }^{\circ} \mathrm{C}$ ), with $0-2.5 \% \mathrm{NaCl}$ (optimum $0-1.5 \% \mathrm{NaCl}$ ) and at $\mathrm{pH} 6.5$ 10.5 (optimum pH 7.0-9.5). Good growth occurs on SPC and tryptic soy agars, but not on MacConkey or cetrimide agars. No haemolysis occurs on $5 \%$ sheep blood agar. Catalase and oxidase activities are present. Casein and tributyrin are hydrolysed. The following results are obtained from API 20E and API 20NE strips after $48 \mathrm{~h}$ of incubation: glucose, arabinose, mannose, maltose and malic acid are assimilated, indole and acetoin are produced, $\mathrm{H}_{2} \mathrm{~S}$ is not produced, $\beta$-galactosidase activity is present, aesculin and gelatin are hydrolysed (gelatin only after $48 \mathrm{~h}$ incubation), urea is not hydrolysed, citrate is not utilized and activities of arginine dihydrolase, lysine and ornithine decarboxylases and tryptophan deaminase are absent. In API $50 \mathrm{CH}$ strips incubated for $48 \mathrm{~h}$, acid is produced from D-glucose, D-fructose, maltose, D-lactose, sucrose and inulin. In API ZYM strips incubated for $4.5 \mathrm{~h}$, activities of alkaline and acid phosphatases, esterase (C4), esterase lipase (C8), lipase (C14), leucine arylamidase, valine arylamidase, cystine arylamidase, naphthol-AS-BIphosphohydrolase and $\beta$-galactosidase are present. The dominant cellular fatty acids are $15: 0$ iso $(41.6 \%), 15: 0$ anteiso $(16.6 \%)$ and $17: 0$ iso $3-\mathrm{OH}(10.3 \%)$. The following fatty acids are present as minor components: summed feature 3 (comprising 15:0 iso $2-\mathrm{OH}$ and/or $16: 1 \omega 7 c$; $8.9 \%), 13: 0$ iso $(5.4 \%), 16: 03-\mathrm{OH}(3.3 \%), 17: 1$ iso $\omega 9 c$ $(2.7 \%), 15: 0$ iso $3-\mathrm{OH}(2.2 \%), 16: 0(1.9 \%)$, unknown $16.582(1.6 \%), 14: 0(1.1 \%), 16: 0$ iso $3-\mathrm{OH}(1.1 \%)$ and $17: 02-\mathrm{OH}(1.0 \%)$. Traces $(<1 \%)$ of $13: 0$ anteiso, $14: 0$ iso, $15: 0$ and 15:0 2-OH are also present. The $\mathrm{G}+\mathrm{C}$ content of the DNA of the type strain is $37.8 \mathrm{~mol} \%$.

The type strain is strain $\mathrm{H} 38^{\mathrm{T}}\left(=\mathrm{LMG} 24029^{\mathrm{T}}=\mathrm{DSM}\right.$ $\left.19056^{\mathrm{T}}\right)$, isolated from raw milk in Israel.

\section{Acknowledgements}

This work was supported by a grant from Tnuva Research Institute, Israel.

\section{References}

Ben-Ze'ev, I. S., Levy, E., Eilam, T. \& Anikster, Y. (2005). Whole-cell fatty acid profiles - a tool for species and subspecies classification in the Puccinia recondita complex. J Plant Pathol 87, 187-197.
Bernardet, J.-F., Nakagawa, Y. \& Holmes, B. (2002). Proposed minimal standards for describing new taxa of the family Flavobacteriaceae and emended description of the family. Int J Syst Evol Microbiol 52, 1049-1070.

Bernardet, J.-F., Vancanneyt, M., Matte-Tailliez, O., Grisez, L., Tailliez, P., Bizet, C., Nowakowski, M., Kerouault, B. \& Swings, J. (2005). Polyphasic study of Chryseobacterium strains isolated from diseased aquatic animals. Syst Appl Microbiol 28, 640-660.

Bernardet, J.-F., Hugo, C. \& Bruun, B. (2006). The genera Chryseobacterium and Elizabethkingia. In The Prokaryotes: a Handbook on the Biology of Bacteria, 3rd edn, vol. 7, pp. 638-676. Edited by M. Dworkin, S. Falkow, E. Rosenberg, K. H. Schleifer \& E. Stackebrandt. New York: Springer.

de Beer, H., Hugo, C. J., Jooste, P. J., Willems, A., Vancanneyt, M., Coenye, T. \& Vandamme, P. A. R. (2005). Chryseobacterium vrystaatense sp. nov., isolated from raw chicken in a chicken processing plant. Int J Syst Evol Microbiol 55, 2149-2153.

de Beer, H., Hugo, C. J., Jooste, P. J., Vancanneyt, M., Coenye, T. \& Vandamme, P. (2006). Chryseobacterium piscium sp. nov., isolated from fish of the South Atlantic Ocean off South Africa. Int J Syst Evol Microbiol 56, 1317-1322.

Fautz, E. \& Reichenbach, H. (1980). A simple test for flexirubin-type pigments. FEMS Microbiol Lett 8, 87-91.

Felske, A., Rheims, H., Wolterink, A., Stackebrandt, E. \& Akkermans, A. D. (1997). Ribosome analysis reveals prominent activity of an uncultured member of the class Actinobacteria in grassland soils. Microbiology 143, 2983-2989.

Gallego, V., Garcia, M. T. \& Ventosa, A. (2006). Chryseobacterium hispanicum sp. nov., isolated from the drinking water distribution system of Sevilla, Spain. Int J Syst Evol Microbiol 56, 1589-1592.

González, C. J., Santos, J. A., Garcia-Lopez, M. L. \& Otero, A. (2000). Psychrobacters and related bacteria in freshwater fish. J Food Prot 63, 315-321.

Holmes, B., Owen, R. J., Steigerwalt, A. G. \& Brenner, D. J. (1984). Flavobacterium gleum, a new species found in human clinical specimens. Int J Syst Bacteriol 34, 21-25.

Hugo, C. J., Jooste, P. J., Segers, P., Vancanneyt, M. \& Kersters, K. (1999). A polyphasic taxonomic study of Chryseobacterium strains isolated from dairy sources. Syst Appl Microbiol 22, 586-595.

Hugo, C. J., Segers, P., Hoste, B., Vancanneyt, M. \& Kersters, K. (2003). Chryseobacterium joostei sp. nov., isolated from the dairy environment. Int J Syst Evol Microbiol 53, 771-777.

Kämpfer, P., Dreyer, U., Neef, A., Dott, W. \& Busse, H.-J. (2003). Chryseobacterium defluvii sp. nov., isolated from wastewater. Int J Syst Evol Microbiol 53, 93-97.

Kim, K. K., Bae, H.-S., Schumann, P. \& Lee, S.-T. (2005a). Chryseobacterium daecheongense sp. nov., isolated from freshwater lake sediment. Int J Syst Evol Microbiol 55, 133-138.

Kim, K. K., Kim, M. K., Lim, J. H., Park, H. Y. \& Lee, S. T. (2005b). Transfer of Chryseobacterium meningosepticum and Chryseobacterium miricola to Elizabethkingia gen. nov. as Elizabethkingia meningoseptica comb. nov. and Elizabethkingia miricola comb. nov. Int J Syst Evol Microbiol 55, 1287-1293.

Kumar, S., Tamura, K. \& Nei, M. (2004). MEGA3: integrated software for molecular evolutionary genetics analysis and sequence alignment. Brief Bioinform 5, 150-163.

Mesbah, M., Premachandran, U. \& Whitman, W. B. (1989). Precise measurement of the $\mathrm{G}+\mathrm{C}$ content of deoxyribonucleic acid by highperformance liquid chromatography. Int J Syst Bacteriol 39, 159-167.

Park, M. S., Jung, S. R., Lee, K. H., Lee, M. S., Do, J. O., Kim, S. B. \& Bae, K. S. (2006). Chryseobacterium soldanellicola sp. nov. and 
Chryseobacterium taeanense sp. nov., isolated from roots of sand-dune plants. Int J Syst Evol Microbiol 56, 433-438.

Peterson, W. J., Bell, T. A., Etchells, J. L. \& Smart, W. W. G., Jr (1954). A procedure for demonstrating the presence of carotenoid pigments in yeasts. J Bacteriol 67, 708-713.

Quan, Z. X., Kim, K. K., Kim, M. K., Jin, L. \& Lee, S. T. (2007). Chryseobacterium caeni sp. nov., isolated from bioreactor sludge. Int $J$ Syst Evol Microbiol 57, 141-145.

Shen, F.-T., Kämpfer, P., Young, C.-C., Lai, W.-A. \& Arun, A. B. (2005). Chryseobacterium taichungense sp. nov., isolated from contaminated soil. Int J Syst Evol Microbiol 55, 1301-1304.

Shimomura, K., Kaji, S. \& Hiraishi, A. (2005). Chryseobacterium shigense sp. nov., a yellow-pigmented, aerobic bacterium isolated from a lactic acid beverage. Int J Syst Evol Microbiol 55, 1903-1906.

Tai, C. J., Kuo, H. P., Lee, F. L., Chen, H. K., Yokota, A. \& Lo, C. C. (2006). Chryseobacterium taiwanense sp. nov., isolated from soil in Taiwan. Int J Syst Evol Microbiol 56, 1771-1776.

Vandamme, P., Bernardet, J.-F., Segers, P., Kersters, K. \& Holmes, B. (1994). New perspectives in the classification of the flavobacteria: description of Chryseobacterium gen. nov., Bergeyella gen. nov., and Empedobacter nom. rev. Int J Syst Bacteriol 44, 827-831.

Weon, H. Y., Kim, B. Y., Yoo, S. H., Kwon, S. W., Cho, Y. H., Go, S. J. \& Stackebrandt, E. (2006). Chryseobacterium wanjuense sp. nov., isolated from greenhouse soil in Korea. Int J Syst Evol Microbiol 56, 1501-1504.

Wilson, K. (1987). Preparation of genomic DNA from bacteria. In Current Protocols in Molecular Biology, pp. 2.4.1-2.4.5. Edited by F. M. Ausubel, R. Brent, R. E. Kingston, D. D. Moore, J. G. Seidman, J. A. Smith \& K. Struhl. New York: Green Publishing \& Wiley-Interscience.

Yabuuchi, E., Kaneko, T., Yano, I., Moss, C. W. \& Miyoshi, N. (1983). Sphingobacterium gen. nov., Sphingobacterium spiritivorum comb. nov., Sphingobacterium multivorum comb. nov., Sphingobacterium mizutae sp. nov., and Flavobacterium indologenes sp. nov.: glucose nonfermenting Gram-negative rods in CDC groups IIK-2 and IIb. Int J Syst Bacteriol 33, 580-598.

Young, C. C., Kämpfer, P., Shen, F. T., Lai, W. A. \& Arun, A. B. (2005). Chryseobacterium formosense sp. nov., isolated from the rhizosphere of Lactuca sativa L. (garden lettuce). Int J Syst Evol Microbiol 55, 423-426. 